\title{
Challenges to Online Engineering Education during the Covid-19 Pandemic in Eastern Visayas, Philippines
}

\author{
Perante Wenceslao \\ Eastern Visayas State University, Philippines \\ https://orcid.org/0000-0002-1511-2430 \\ Gomba Felisa \\ Samar State University, Philippines \\ https://orcid.org/0000-0001-8744-148X
}

\begin{abstract}
The Covid-19 pandemic halted the normal operations of schools and universities around the world. Various educational institutions, including the Philippines Commission on Higher Education (CHED), adapted to the limitations caused by the pandemic and recommended online education to reach students and learners remotely. This research investigated the challenges to online engineering education in higher educational institutions (HEIs) $(n=4)$ in Eastern Visayas, Philippines. Challenges and problems experienced by faculty $(n=25)$ and students $(n=421)$ were gathered through an online survey on December 2020 using Google Forms. Findings indicate that $98 \%$ of the respondents were gadget ready for online education for the first semester of SY 2020-2021, and the primary type implemented is Online Education Only (OEO) $(n=369)$. The majority of the respondents $(94 \%)$ believed that the quality of education suffered from the sudden shift to online education and $64 \%$ believed it is not as effective as the traditional face-to-face classroom interaction. Post Covid-19, 60\% of the faculty prefers Blended Education (BE); while the students $(65 \%)$ prefer the traditional classroom face-toface interaction. The challenges faced by the respondents during the Covid-19 analysed through qualitative content analysis can be categorised into Personal Challenges, Limited Social Interaction, Technology Difficulties, Assessment Issues, and Concerns on Learning Materials and Methods.
\end{abstract}

Keywords: coronavirus pandemic; Covid-19; online engineering education challenges; Philippines

\section{Introduction}

Covid-19 was first reported in Wuhan, China in late 2019 (Huang et al., 2020; Mackenzie \& Smith, 2020; Wu, Yi et al., 2020) and since then it has spread all over 
the world. On December 1, 2020 cases of Covid-19 had cumulative numbers of over 61.8 million reported cases and 1.4 million deaths globally. In the Philippines, as of December 7, 2020, there have been 439,834 confirmed cases with 8,554 deaths (WHO, 2020).

The pandemic disrupted the way of life all over the world. To contain the spread of the virus, policies such as sheltering, social distancing, washing of hands, wearing a face mask and quarantine procedures were recommended as a standard practice (Adedoyin \& Soykan, 2020; Radha et al., 2020; Rajab et al., 2020; Suryaman et al., 2020); further, limited allowable groupings made traditional faceto-face education not feasible. This resulted in the transformation of the way education was delivered, from the classroom in-person interaction to online education through the internet (Machado et al, 2020; Radha et al., 2020; Suryaman et al., 2020). Educational institutions all over the world, including the Philippines Commission on Higher Education (CHED, 2020), adapted to the limitations prompted by the pandemic and recommended online learning education to reach students and learners safely and remotely. Online learning during the pandemic had been supported and implemented in many countries around the world (Goldschmidt, 2020).

Online learning is the use of the internet and related technologies and devices to develop, deliver and manage education programmes (Fry, 2001; Means et al., 2009). The advances in technological innovation and the improvement in internet speed and accessibility have increased the initiatives and programs for online learning in the past couple of decades (Tallent-Runnels et al., 2006). The use of hardware like desktops, laptops, smartphones and various software applications such as online videos, email, video conferencing, chatrooms and learning management systems are some of the primary tools used in online education.

Online education is not new, it has been a part of educational tools in many educational institutions in many countries (Allen \& Seaman, 2008; LarreamendyJoerns \& Leinhardt, 2006), but the Covid-19 pandemic accelerated its widespread, if not obligatory use for lack of other options. Many colleges and universities had been implementing a transition from traditional face-to-face teaching to online learning, and to a combination of online and traditional education called blended learning before Covid-19 (Bonk \& Graham, 2012).

Online learning has its advantages, such as flexibility in study time and location (O'Donoghue et al., 2004; Smedley, 2010), interactivity (Leszczyński et al., 2018; Wagner et al., 2008), self-pacing (Palaigeorgiou \& Papadopoulou, 2018), accessibility and cost savings ((O'Donoghue et al., 2004). It also has many issues, concerns, and challenges (Dumford \& Miller, 2018) that have been made apparent during the Covid-19 pandemic, for example, there are concerns about the quality of education resulting from the sudden shift to online education (Hodges et al., 2020). The adequately planned online education and learning that is characterised with quality could be different from the courses presented online as a response to a crisis, i.e., Covid-19 “emergency remote teaching" (Hodges et al., 2020). 
Another concern is the unsuitability of certain courses for online education (Machado et al., 2020). The compatibility of online learning with social science and humanities has been proved effective (Leszczyński et al., 2018); however, other researchers have disputed its compatibility with sports sciences, engineering and medical sciences; this is because in-person practical experiences and hands-on instructional activities are a required and essential part for these courses (Leszczyński et al., 2018; Machado et al., 2020).

This study was undertaken to investigate the concerns and challenges faced by students and faculty in online engineering education in Eastern Visayas, Philippines.

\section{Methodology}

This study was conducted in Eastern Visayas Philippines (Figure 1). Eastern Visayas consists of three main islands: Samar, Leyte and Biliran, and has a population of 4,440,150 inhabitants as of 2015 (PSA, 2015). Eastern Visayas is home to several state universities: University of Eastern Philippines (UEP), Visayas State University (VSU), Eastern Visayas State University (EVSU), Southern Leyte State University (SLSU), Naval State University (NSU), Eastern Samar State University (ESSU), and Samar State University (SSU).

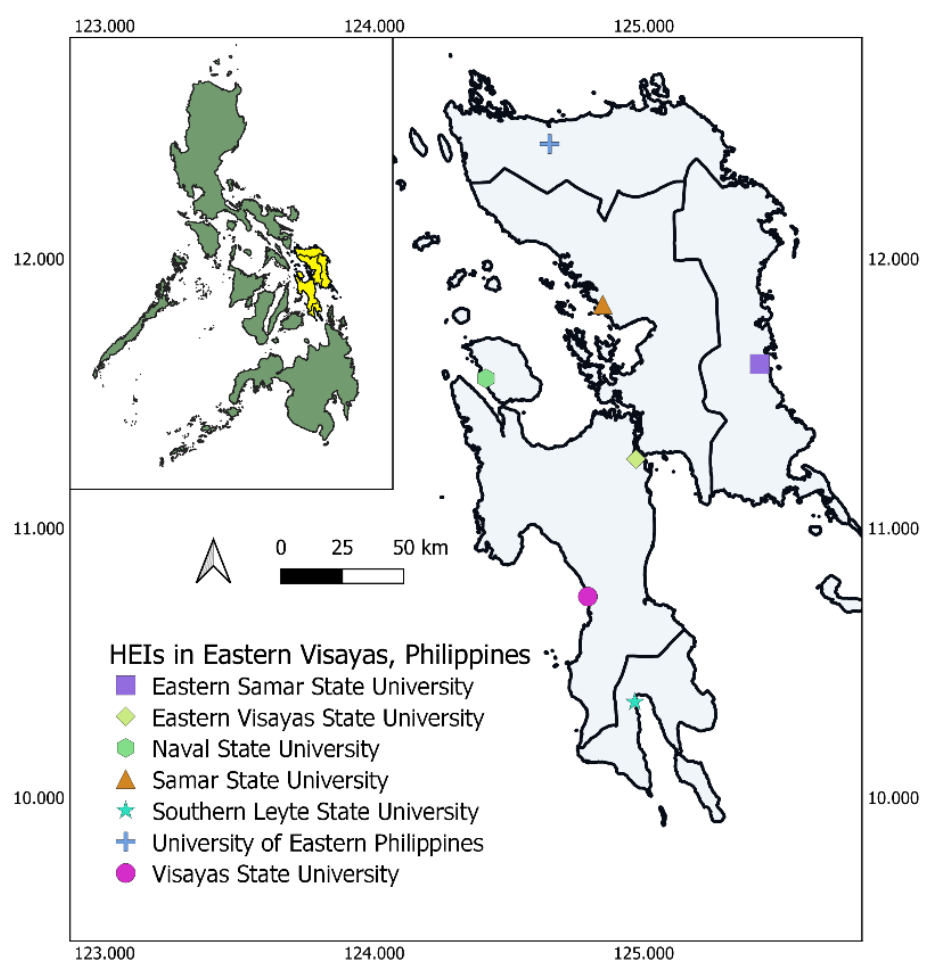

Figure 1. Location of the HEIs in Eastern Visayas, Philippines that participated in the survey: EVSU $(n=308), \operatorname{ESSU}(n=80), \operatorname{SSU}(n=40)$, and NSU $(n=18)$.

The researchers developed an online survey questionnaire using Google Forms ${ }^{\circledR}$ (Google LLC, Mountain View, CA). The questions were composed of three parts: (1) general information of the respondents, (2) pre-Covid-19 readiness for online education, and (3) experiences and challenges during the online education 
programme implemented during the first semester (September to December 2020) of the school year 2020-2021. The questions were a combination of closed and open-ended queries to provide flexibility and to generate descriptive answers from respondents. The questionnaire was validated by inviting three faculty and three students to provide feedback and comments on the survey questions. After the comments were incorporated into the questionnaire; it was pilot tested to prospective respondents (students, $n=21$; faculty, $n=10$ ) to determine the questionnaire's internal consistency and the calculated Cronbach's alpha value was 0.776 .

The questionnaire administration to respondents was conducted online and to obtain a large number of responses, an email introducing the research and the web address of the Google Forms survey was sent to HEIs with engineering courses in Eastern Visayas inviting them to participate in the survey. Before the respondents filled the survey properly, they were first informed of its purpose and how their responses will be treated with confidentiality. The survey questionnaire can be accessed through this link: https:/ / forms.gle/X6L1yahVhksBru419

Data generated from the survey were processed into categories based on profession: student or faculty; and according to time frame: pre and during Covid19. The results of the open-ended questions were processed and analysed by coding using quantitative content analysis (Züll, 2016). Data analysis employed descriptive statistics using the software SPSS Version 21.0; while the map was created using QGIS Desktop 3.16.5.

\section{Results}

\subsection{Respondents Profile}

The survey generated 446 responses from December 1 to 20, 2020. The faculty respondents were composed of females $(n=9)$ and males $(n=16)$; having a mean age of 35.88 years old, with the oldest at 59 and the youngest at 24 years old; the mean teaching experience was 8.12 years, with the highest at 32 years and lowest at one year. Conversely, the students' respondents were composed of females $(n=187)$ and males $(n=234)$, with a mean age of 20.3 years old (Table 1). Further, most of the student respondents were Bachelor of Science in Civil Engineering (BSCE) students $(n=379)$, Bachelor of Science in Electrical Engineering $(n=21)$, and other Engineering Courses $(n=21)$. The respondents' distribution in terms of HEIs were EVSU $(n=308), \operatorname{ESSU}(n=80), \operatorname{SSU}(n=40$, and NSU $(n=18)$; while the year level is fairly distributed as follows: 1 st year $(n=119), 2^{\text {nd }}$ year $(n=123), 3^{\text {rd }}$ year $(\mathrm{n}=105)$, and $4^{\text {th }}$ year $(\mathrm{n}=74)$.

\subsection{Gadget and Internet Connection}

The majority (98\%) of the respondents owned a smartphone, and $32.3 \%$ have a laptop computer, $2.9 \%$ owned a Tablet, while the others have a desktop $(n=7)$. Before Covid-19, 35.3\% had a home internet connection, while $61.4 \%$ had no home internet connection. However, this changed during the pandemic, home internet connection increased to $70.1 \%$, while $29.9 \%$ use mobile data to connect to the internet. 
Table 1: The respondents' demographic profile

\begin{tabular}{llcc}
\hline & Demographic Characteristic & Frequency $(\mathrm{n}=446)$ & Percent \\
\hline Gender & Male & 250 & $56.2 \%$ \\
& Female & 196 & $43.8 \%$ \\
\hline Profession & Faculty & 25 & $5.6 \%$ \\
& PhD. & 3 & $1 \%$ \\
& Masters & 15 & $4 \%$ \\
& MS Student & 7 & $2 \%$ \\
& Student & 421 & $94.4 \%$ \\
& BSCE & 379 & $85 \%$ \\
& BSEE & 21 & $5 \%$ \\
& Others & 21 & $5 \%$ \\
\hline \multirow{4}{*}{ HEI } & EVSU & 308 & $69 \%$ \\
& ESSU & 80 & $18 \%$ \\
& SSU & 40 & $9 \%$ \\
& NSU & 18 & $4 \%$ \\
\hline Age & Mean: 21.2 years old & 446 & $100 \%$ \\
& $\leq 19$ years old & 166 & $37 \%$ \\
& 20 to 21 years old & 180 & $40 \%$ \\
& 22 to 30 years old & 82 & $18 \%$ \\
& $\geq 31$ years old & 18 & $4 \%$ \\
\hline Student Year Level & 1st Year & 119 & $27 \%$ \\
& 2nd Year & 123 & $28 \%$ \\
& 3rd Year & 105 & $24 \%$ \\
& $4^{\text {th }}$ Year & 74 & $17 \%$ \\
\hline
\end{tabular}

\subsection{Respondents' Perceptions on Online Education}

The majority of the respondents $(99 \%)$ reported that their HEI is implementing online education for the first semester of the school year 2020-2021. Most of the respondents $(82.6 \%)$ were taking Online Education Only (OEO) (no personal faceto-face interaction); while $8.7 \%$ of the respondents reported Blended Education (BE) (a combination of online and personal face-to face-interaction); and the rest $(n=35)$ reported Modular Online Education (MOE) (a combination of printed modules and online).

Table 2: The respondents' perceptions of online education (OE) and preference of education delivery post Covid-19.

\begin{tabular}{lllll}
\hline $\begin{array}{l}\text { Preference of OE Delivery } \\
\text { Post Covid-19 }\end{array}$ & $n$ & Online only & Blended & Face-to-Face only \\
\hline Faculty & 25 & $8 \%$ & $60 \%$ & $32 \%$ \\
Students & 421 & $3 \%$ & $32 \%$ & $65 \%$ \\
\hline Consequence of OE & $\boldsymbol{n}$ & Yes & No & Somewhat \\
\hline Education Quality Declined? & 444 & $94 \%$ & $4 \%$ & $2 \%$ \\
Is Online Education Effective? & 441 & $13 \%$ & $64 \%$ & $22 \%$ \\
\hline OE Effect on & Poor & Fair & Good & Very Good \\
\hline Quality of Teaching $(\mathrm{n}=25)$ & $4 \%$ & $12 \%$ & $72 \%$ & $12 \%$ \\
Quality of Learning $(\mathrm{n}=421)$ & $12 \%$ & $39 \%$ & $42 \%$ & $6 \%$ \\
\hline
\end{tabular}

Most of the respondents (94\%) believed that the quality of education declined due to the sudden shift to online education and $64 \%$ believed it is not as effective as the traditional face-to-face interaction (Table 2). 
Table 3: The challenges, problems, and difficulties faced by the respondents in online education during the Covid-19 Pandemic in Eastern Visayas, Philippines.

\begin{tabular}{|c|c|c|c|}
\hline Category & Sub-Category & $\begin{array}{c}\text { Responses } \\
(\mathrm{n}=446)\end{array}$ & $\begin{array}{c}\text { Percent } \\
\text { Response }\end{array}$ \\
\hline \multirow{6}{*}{$\begin{array}{l}\text { Personal } \\
\text { Challenges }\end{array}$} & Time-Management & 338 & $76 \%$ \\
\hline & $\begin{array}{l}\text { Pandemic Related Health Issues: Anxiety, } \\
\text { Stress, Backpain }\end{array}$ & 300 & $67 \%$ \\
\hline & Lack of Self-Discipline & 165 & $37 \%$ \\
\hline & Home Environment \& Distractions & 140 & $31 \%$ \\
\hline & Lack of Motivation & 119 & $26 \%$ \\
\hline & $\begin{array}{l}\text { Financial Limitations (Money for Internet } \\
\text { Connection) }\end{array}$ & 33 & $7 \%$ \\
\hline \multirow{4}{*}{$\begin{array}{l}\text { Limited Social } \\
\text { Interaction }\end{array}$} & Lack of Face-to-Face Interaction & 231 & $52 \%$ \\
\hline & $\begin{array}{l}\text { Lack of Student Community or Campus } \\
\text { Environment }\end{array}$ & 67 & $15 \%$ \\
\hline & Lack of Student Group Activity \& Sharing & 49 & $11 \%$ \\
\hline & $\begin{array}{l}\text { Limited or Lack of Instant Feedback from } \\
\text { Teachers }\end{array}$ & 36 & $8 \%$ \\
\hline \multirow{7}{*}{$\begin{array}{l}\text { Technology } \\
\text { Difficulties }\end{array}$} & Slow Internet Speed & 411 & $92 \%$ \\
\hline & Communication Problems (Audio \& Video) & 271 & $60 \%$ \\
\hline & $\begin{array}{l}\text { Unfamiliarity with New Technology or New } \\
\text { Software Applications }\end{array}$ & 238 & $53 \%$ \\
\hline & Learning Curve Too High & 147 & $33 \%$ \\
\hline & $\begin{array}{l}\text { Lagging Connection or Lack of Signal } \\
\text { Coverage }\end{array}$ & 141 & $32 \%$ \\
\hline & Power Outage & 32 & $7 \%$ \\
\hline & HEIs Poor Technology Infrastructure & 29 & $6 \%$ \\
\hline \multirow[t]{3}{*}{$\begin{array}{l}\text { Assessment } \\
\text { Issues }\end{array}$} & $\begin{array}{l}\text { Student Assessment Limited to Multiple } \\
\text { Choice and Essay }\end{array}$ & 200 & $45 \%$ \\
\hline & Easy to Cheat on Online Exam & 78 & $17 \%$ \\
\hline & Poor Quality of Student Assessment & 33 & $7 \%$ \\
\hline \multirow{5}{*}{$\begin{array}{l}\text { Concerns on } \\
\text { Learning } \\
\text { Materials and } \\
\text { Methods }\end{array}$} & $\begin{array}{l}\text { Higher than Normal Assignments, Tasks, } \\
\text { and Quizzes }\end{array}$ & 188 & $42 \%$ \\
\hline & $\begin{array}{l}\text { No Actual Laboratory Activities and } \\
\text { Experiments; More on Theory }\end{array}$ & 152 & $34 \%$ \\
\hline & $\begin{array}{l}\text { Lack of Hands-on, Real Life Exposure, Field } \\
\text { Experience and Trips }\end{array}$ & 148 & $33 \%$ \\
\hline & $\begin{array}{l}\text { Some Lessons are Difficult to Understand } \\
\text { Without In-person Lecture }\end{array}$ & 69 & $15 \%$ \\
\hline & $\begin{array}{l}\text { Limited Online Meetings; Low to No } \\
\text { Guidance from the Teachers }\end{array}$ & 36 & $8 \%$ \\
\hline
\end{tabular}

\subsection{Challenges to Online Engineering Education}

The respondents were asked open-ended questions about the challenges, problems, limitations and difficulties with online education. The responses were analysed qualitatively by coding the frequencies into categories and subcategories. The top challenges identified in each category were as follows: Time- 
Management $(n=338)$ had the most responses in the category of personal challenges; Lack of Face-to-Face Interaction $(n=231)$ for the category of Limited Social Interaction; Slow Internet Speed $(n=411)$, for Technology Difficulties; Student Assessment-Limited to Multiple Choice and Essay $(n=200)$ for Assessment Issues; and Higher than Normal Assignments, Tasks, and Quizzes(n=188) for Concerns on Learning Materials and Methods (Table 3).

\section{Discussion}

The majority $(99 \%)$ of respondents were involved in online education for the first semester of SY 2020-2021 and most (82.6\%) are into Online Education Only (OEO), which is understandable because of the fear of being infected with Covid-19. An OEO approach may not be the most appropriate given that most of the respondents $(50 \%)$ had no online education experience, but, for lack of other options, perhaps, this is reasonable. Even so, there are concerns about the quality of education ensuing from this hasty shift to online learning (Hodges et al., 2020). The sudden shift to online education at a large scale on short notice would certainly face difficulties and problems. A particular concern in developing countries like the Philippines is the poor internet infrastructure and the frequency of power interruption. Likewise, HEIs have many concerns including: the need to adjust or revise the curriculum to suit to online teaching environment; the need for appropriate logistics (software, hardware, learning management systems and others); the need for training of faculty and staff (skills on online teaching including creation and development of online teaching materials); the need to revise student assessments, tasks and approaches; and the need to adjust the length of the school semester to give ample time for preparations for all stakeholders, to name but a few. These concerns cannot be suddenly addressed given the limited time and resources of most of the HEIs; nevertheless, the Philippines started the first semester on August 17, 2020.

Faculty respondents perceived the impact of online education to quality of teaching as Good (72\%). While the students believe the impact of online education to quality of learning is Fair (39\%) and Good (42\%). Additionally, the education delivery preference post Covid-19 for faculty respondents (60\%) is Blended Education (BE); while $65 \%$ of the students prefer the traditional classroom faceto-face interaction (FTFI).

Furthermore, the challenges faced by the respondents during the pandemic (Table 3) can be grouped into five categories: Personal Challenges, Limited Social Interaction, Technology Difficulties, Assessment Issues, and Concerns on Learning Materials and Methods. These concerns, issues, and challenges are discussed below; possible methods on how to address these challenges and how to improve the current online education are presented.

(1) Personal challenges identified by the respondents are poor time-management, increased stress, lack of self-discipline, lack of motivation and lack of financial resources for internet connection. These challenges are also common in traditional classroom education, but probably a bigger concern in an online education setting. The OEO provides a higher level of flexibility and autonomy 
to students and can be characterised as an online self-directed learning approach where students take responsibility for their time, their learning needs, their learning goals, their learning strategies, the sequence, pace, and the amount of content to be learned (Kebritchi et al., 2017) making motivation and self-discipline vital in the students' learning process as motivation for learning in an online setting is critical in the success of learners and in increasing learners' retention (Kebritchi et al., 2017; Saade et al, 2017). The HEIs maybe can address these concerns by offering a programme to help students in developing strong attitudes and dispositions towards online learning, i.e., improving self-discipline, cultivating motivation, and learning time-management skills. Also, various forms of support from families, teachers and schoolmates can be explored to help maximise the students' ability to learn through online education (OECD, 2020). Further, to address the students' financial concerns, the HEIs and the government should provide financial aid to students. particularly for internet connection fees because, if this is not addressed, this could lead to some students being left behind.

(2) Limited social interaction such as lack of face-to-face meetings, lack of campus atmosphere and group activities, limited or lack of instant feedback from teachers are the challenges in this category. If the OEO approach is continued for some time, then maybe HEIs should develop methods and approaches to increase online interaction through online engagement activities such as the use of interactive and dynamic multimedia content and games. HEIs should also conduct training for teachers to effectively use online tools to improve student engagement and participation, including adopting pedagogical teaching practices suited to online context; or the use of innovative teaching methods to engage students and to stimulate their proactive behaviour (Ferri et al., 2020) and help improve online social interaction between and among teachers and students. Otherwise, this concern can easily be mitigated by shifting to a BE approach, which provides a limited face-to face-interaction. This study recognises that there is no substitute for teacher-student interaction, which is vital in the learning process of students particularly in the primary and secondary levels; however, to mitigate problems of inclusion, other studies suggested using a BE approach (Ferri et al., 2020), whenever possible, particularly at the tertiary level.

(3) Technology difficulties like unfamiliarity with new software applications, slow internet speed, poor signal coverage, audio and video communication problems, and HEIs' poor technology infrastructure are the challenges in this category. The sudden shift to OEO was a new experience for most teachers and students; and this caught teachers unprepared and struggling with unfamiliar teaching methods and software applications, forcing them to employ trial-and-error approaches resulting in a minimalist usage of what software and online tools are capable of providing (Do, 2020). However, these challenges can be addressed by HEIs through online training on new software applications (particularly its various functionalities and its full potential for use in OE) for faculty and students as it is important that both have knowledge about using communication technology platforms, not only for face-to-face teaching, but, importantly, for BE and OEO (Ogbonnaya et al., 2020). Further, HEIs should allocate a budget for technology hardware and software to improve its poor technology infrastructure (i.e., limited 
server capacity, limited upload memory, and Learning Management System failure to handle heavy traffic during peak hours). HEIs should recognise that, now, and in the future, Information and Communications Technology (ICT) infrastructure, as well as its software support system, is going to be an integral part of teacher-student interaction and thus should be included in its budget allocations. On the concern of slow internet speed and poor signal coverage, this is a technological issue and challenges challenge connected with governance and policies related to economic development and technology adoption, not only in the Philippines but also in many other countries as well. Thus, governments together with development agencies and internet service providers should address the slow internet speed and poor signal coverage to minimise the existing digital divide.

(4) Assessment challenges such as limited methods of student assessment, easy to cheat on online exams, and poor quality of assessment are some of the challenges identified by the respondents. These problems are not surprising since most HEIs have no clear policy and guidelines on online teaching and more so on online assessment (Guangul et al., 2020). In HEIs, assessments are used to (1) support learning, (2) to execute accountability, and (3) to provide certification, progress and transfer (Capsim, 2020). It is also aimed to determine competence, gaps and progress so learners can adapt their learning strategies and teachers their teaching strategies (Guangul et al., 2020). These assessment concerns can be attributed to the lack of preparation and inexperience in online education by most HEIs, teachers and students in Eastern Visayas. However, now that both students and faculty have knowledge and experience on online education, these issues can easily be addressed through various creative ways, for example, on the issue that it is easy to cheat on online exams, certain software can be used for remote assessment that uses webcams to track student activity during an exam and can warn or assist the teacher whenever suspicious actions are taken by the students (Rutgers, 2020). If Google Forms are used as an assessment tool, it could be partnered with a "timer and proctor" add-on that time limits the exam, and provides proctoring through a camera that records the student's actions while taking the exam.

(5) Concerns on learning materials and methods included higher than normal assignments, tasks and quizzes; no actual laboratory activities and experiments; teaching approach is more on theory and lacks hands-on real-life exposure and field experience; and minimal to no guidance from the teachers. In another study (Armstrong-Mensah et al., 2020), students reported that the transition to online classes increased their academic workload in the form of written reports and assignments, reflection papers, quizzes and discussion posts. This increase in student workload could be the teacher's way to compensate for the lack of faceto-face interaction and to ensure that the students are learning the subject. To address the lack of laboratory and hands-on experience, perhaps HEIs should train teachers to use digital interactive multimedia content, including digital laboratories and other specific online skills to supplement the need for experiments and hands-on learning (Ferri et al., 2020). Also, OEO may not be suitable for courses like engineering where in-person experiences and hands-on 
instructional lessons are an essential part of learning; the HEIs should consider this nature of the course.

Further, this study opines that, given the challenges, concerns and issues discussed above, the best approach to education delivery post Covid-19 is, perhaps, BE for two main reasons: Firstly, most of the challenges identified above can be fully, if not, partially addressed through a BE approach. These issues were all the components of (2) limited social interaction, (4) assessment challenges, and (5) concerns on learning materials and methods; furthermore, while faculty and students are transitioning and learning, new software applications and online tools as identified in (3) as technology difficulties; and while the students are in the process of learning, motivation development and self-discipline skills, as identified in (1) are personal challenges; a BE approach can, possibly, supplement and hasten the learning process of both faculty and students. Secondly, a BE approach is more efficient, which helps in saving time, money and resources for all stakeholders compared to an FTFI mode of education delivery. To cite an example, with reduced FTFI, both faculty and students have more time for other tasks, possibly resulting in reduced travel (and related expenses) due to a reduced frequency of travel to and from the campus, not to mention the reduced carbon footprint related to less frequent FTFI activities.

In summary, this study believes that online education could become a permanent part of HEIs mode of education delivery in Eastern Visayas. The reasons are: HEIs have invested in Learning Management Systems; modules and online education materials have been developed; the respondents have acquired experience, new skills and knowledge on online education; and the faculty believes that online education had a good impact on their quality of teaching, thus most faculty respondents prefer a BE education delivery post Covid-19.

\section{Conclusion and Recommendations}

The Covid-19 pandemic has frozen the normal operations of schools and universities in the Philippines. The Commission on Higher Education adapted to the limitations caused by the pandemic and endorsed online education for the SY 2020-2021; as a result, students and faculty faced various challenges and issues related to online education (Table 3 ). This study, thus, recommends the following to address these issues and challenges: (1) HEIs should offer a programme to help students develop strong attitudes towards online learning particularly focused on improving self-discipline, cultivating motivation and developing timemanagement skills; (2) HEIs and the government should provide financial aid to students to cover internet connection fees so as to avoid some students being left behind; (3) HEIs should develop methods and approaches to increase online interaction, including the use of interactive and dynamic multimedia content and games, among other methods; (4) HEIs should conduct trainings for teachers to effectively use online tools to improve student engagement and participation, including adopting pedagogical teaching practices suited to online context; (5) HEIs should provide online training on new software applications used in online education to faculty and students as it is important that they have knowledge about using communication technology platforms; (6) HEIs should allocate a 
budget for technology hardware and software to improve its internet-related communications infrastructure; (7) The government should encourage the internet service providers to improve the slow internet speed and poor signal coverage in many regions of the country; (8) CHED and the HEIs should adjust or maybe modify the curriculum to suit to the online teaching environment, including revising student assessment approaches and methodologies.

This research can serve as reference to future studies related to Covid-19 and its effects on online education. This can also provide policy makers, education administrators and related agencies and stakeholders guidance on how to address the common challenges faced by students and faculty with regard to online education.

\section{Limitations}

This study was constrained in terms of the number of respondents (4 out of 7 HEIs in Eastern Visayas had respondents), and the non-random selection of participants as the study relied on an online survey due to the Covid-19 pandemic-imposed limitations. This study suggests that future researches should endeavour to cover all the HEIs in Eastern Visayas and should employ a random selection of survey participants. Additionally, a separate future study may be needed to validate the perceptions of the respondents on the effectiveness of online education.

Funding: This research was funded by the Samar State University (SSU-Extension Program) and Eastern Visayas State University (Research and Development Extension Programme).

Informed Consent Statement: Informed consent was obtained from all subjects involved in the study.

Data Availability Statement: Data are not publicly available, though may be made available on request from the author.

Conflicts of Interest: The author declares no conflict of interest.

\section{References}

Adedoyin, O. B., \& Soykan, E. (2020). Covid-19 pandemic and online learning: the challenges and opportunities. Interactive Learning Environments, 1-13. https:// doi.org/10.1080/10494820.2020.1813180

Allen, I. E., \& Seaman, J. (2008). Staying the course: Online education in the United States, 2008. Sloan Consortium. https://files.eric.ed.gov/fulltext/ED529698.pdf

Armstrong-Mensah, E., Ramsey-White, K., Yankey, B., \& Self-Brown, S. (2020). COVID-19 and Distance Learning: Effects on Georgia State University School of Public Health Students. Frontiers in Public Health, 8, 547. https://doi.org/10.3389/fpubh.2020.576227

Bonk, C. J., \& Graham, C. R. (2012). The handbook of blended learning: Global perspectives, local designs. John Wiley \& Sons. https:/ / doi.org/10.5465/amle.2008.31413871

Do, J. W. (2020). An investigation of design constraints in the process of converting faceto-face course into online course. Journal of Education $\mathcal{E}$ Culture, 26(2), 153-173. https://doi.org/10.24159/joec.2020.26.2.153 
Dumford, A. D., \& Miller, A. L. (2018). Online learning in higher education: exploring advantages and disadvantages for engagement. Journal of Computing in Higher Education, 30(3), 452-465. https://doi.org/10.1007/s12528-018-9179-z

Ferri, F., Grifoni, P., \& Guzzo, T. (2020). Online learning and emergency remote teaching: Opportunities and challenges in emergency situations. Societies, 10(4), 86. https://doi.org/10.3390/soc10040086

Fry, K. (2001). E-learning markets and providers: some issues and prospects. Education+ Training, (4/5), 233-239. https://doi.org/10.1108/EUM0000000005484

Goldschmidt, K. (2020). The COVID-19 pandemic: Technology use to support the wellbeing of children. Journal of Pediatric Nursing, 53, 88-90. https://doi.org/10.1016/j.pedn.2020.04.013

Guangul, F. M., Suhail, A. H., Khalit, M. I., \& Khidhir, B. A. (2020). Challenges of remote assessment in higher education in the context of COVID-19: a case study of Middle East College. Educational Assessment, Evaluation and Accountability, 32, 1-17. https://doi.org/10.1007/s11092-020-09340-w

Hodges, C., Moore, S., Lockee, B., Trust, T., \& Bond, A. (2020). The difference between emergency remote teaching and online learning. Educause Review, 27, 1-12.

Huang, C., Wang, Y., Li, X., Ren, L., Zhao, J., Hu, Y., ... \& Cao, B. (2020). Clinical features of patients infected with 2019 novel coronavirus in Wuhan, China. The Lancet, 395(10223), 497-506. https:// doi.org/10. 1016/S0140-6736(20)30183-5

Kebritchi, M., Lipschuetz, A., \& Santiague, L. (2017). Issues and challenges for teaching successful online courses in higher education: A literature review. Journal of Educational Technology Systems, 46(1), 4-29. https:// doi.org/10.1177/0047239516661713

Larreamendy-Joerns, J., \& Leinhardt, G. (2006). Going the distance with online education. Review of Educational Research, 76(4), 567-605. https://doi.org/10.3102/00346543076004567

Leszczyński, P., Charuta, A., Łaziuk, B., Gałązkowski, R., Wejnarski, A., Roszak, M., \& Kołodziejczak, B. (2018). Multimedia and interactivity in distance learning of resuscitation guidelines: a randomised controlled trial. Interactive Learning Environments, 26(2), 151-162. https://doi.org/10.1080/10494820.2017.1337035

Machado, R. A., Bonan, P. R. F., Perez, D. E. D. C., \& Martelli Junior, H. (2020). COVID19 pandemic and the impact on dental education: discussing current and future perspectives. Brazilian Oral Research, 34. https:// doi.org/10.1590/1807-3107bor2020.vol34.0083

Mackenzie, J. S., \& Smith, D. W. (2020). COVID-19: a novel zoonotic disease caused by a coronavirus from China: what we know and what we don't. Microbiology Australia, 41(1), 45-50. https:// doi.org/10.1071/MA20013

Means, B., Toyama, Y., Murphy, R., Bakia, M., \& Jones, K. (2009). Evaluation of evidencebased practices in online learning: A meta-analysis and review of online learning studies. https:// repository.alt.ac.uk/629/

O'Donoghue, J., Singh, G., \& Green, C. (2004). A comparison of the advantages and disadvantages of IT based education and the implication upon students. Digital Education Review, (9), 63-76. dialnet.unirioja.es/descarga/articulo/4544753.pdf

OECD Policy Responses to Coronavirus (COVID-19). (2020). Strengthening online learning when schools are closed: The role of families and teachers in supporting students during the COVID-19 crisis. https://read.oecd-ilibrary.org/view/?ref=136_136615o13x4bkowa\&title=Strengthening-online-learning-when-schools-are-closed

Ogbonnaya, U. I., Awoniyi, F. C., \& Matabane, M. E. (2020). Move to Online Learning during COVID-19 Lockdown: Pre-Service Teachers' Experiences in 
Ghana. International Journal of Learning, Teaching and Educational Research, 19(10), 286-303. https://doi.org/10.26803/ijlter.19.10.16

Palaigeorgiou, G., \& Papadopoulou, A. (2019). Promoting self-paced learning in the elementary classroom with interactive video, an online course platform and tablets. Education and Information Technologies, 24(1), 805-823. https://doi.org/10.1007/s10639-018-9804-5

PSA Census of Population. (2015). Region VIII (Eastern Visayas). Retrieved from https://www.psa.gov.ph/sites/default/files/attachments/hsd/pressrelease/R 08.xlsx

Radha, R., Mahalakshmi, K., Kumar, V. S., \& Saravanakumar, A. R. (2020). E-Learning during lockdown of Covid-19 pandemic: A global perspective. International Journal of Control and Automation, 13(4), 1088-1099.

Rajab, M. H., Gazal, A. M., \& Alkattan, K. (2020). Challenges to online medical education during the COVID-19 pandemic. Cureus, 12(7). https://doi.org/10.7759/cureus.8966

Rutgers. (2020). Remote exams and assessments. Retrieved from https:// sasoue.rutgers.edu/teaching-learning/remote-examsassessment\#special-advice-for-open-book-assessment-in-quantitative-courses.

Saadé, R. G., He, X., \& Kira, D. (2007). Exploring dimensions to online learning. Computers in Human Behavior, 23(4), 1721-1739. https:/ / doi.org/10.1016/j.chb.2005.10.002

Smedley, J. (2010). Modelling the impact of knowledge management using technology. OR insight, 23(4), 233-250. https://doi.org/10.1057/ori.2010.11

Suryaman, M., Cahyono, Y., Muliansyah, D., Bustani, O., Suryani, P., Fahlevi, M., ... \& Munthe, A. P. (2020). COVID-19 pandemic and home online learning system: Does it affect the quality of pharmacy school learning? Systematic Reviews in Pharmacy, 11(8), 524-530. https:// doi.org/10.31838/srp.2020.8.74

Tallent-Runnels, M. K., Thomas, J. A., Lan, W. Y., Cooper, S., Ahern, T. C., Shaw, S. M., \& Liu, X. (2006). Teaching courses online: A review of the research. Review of Educational Research, 76(1), 93-135. https://doi.org/10.3102/00346543076001093

Wagner, N., Hassanein, K., \& Head, M. (2008). Who is responsible for e-learning success in higher education? A stakeholders' analysis. Journal of Educational Technology $\mathcal{E}$ Society, 11(3), 26-36. https://doi.org/10.2307/jeductechsoci.11.3.26

WHO. (2020). Weekly epidemiological update - 1 December 2020. Retrieved from www.who.int/publications/m/item/weekly-epidemiological-update---1december-2020

Wu, Y. C., Chen, C. S., \& Chan, Y. J. (2020). The outbreak of COVID-19: an overview. Journal of the Chinese Medical Association, 83(3), 217. https:// doi.org/10.1097/JCMA.0000000000000270

Züll, C. (2016). Open-ended questions. GESIS Survey Guidelines, 3. https://doi.org/10.15465/gesis-sg_en_002 